\title{
Teaching Experience in a Virtual Math Course in COVID-19 Pandemic
}

\author{
Judith Rocha Gamez , Samantha Armijo Martinez \\ Department of Analytical Chemistry, Autonomous University of Nuevo Leon, Nuevo Leon, Mexico \\ Email address: \\ judith.rochagm@uanl.edu.mx (J. R. Gamez), sarmijo.me5021@uanl.edu.mx (S. A. Martínez) \\ ${ }^{*}$ Corresponding author
}

\section{To cite this article:}

Judith Rocha Gamez, Samantha Armijo Martinez. Teaching Experience in a Virtual Math Course in COVID-19 Pandemic. International Journal of Science, Technology and Society. Vol. 9, No. 4, 2021, pp. 182-187. doi: 10.11648/j.ijsts.20210904.15

Received: July 26, 2021; Accepted: August 11, 2021; Published: August 26, 2021

\begin{abstract}
In this work we share the experience of a virtual mathematics course under the modality of competencies at the bachelor's level in the Clinical Chemical Biologist career that is taught at the Faculty of Medicine of the Autonomous University of Nuevo León. Through the use of the Moodle platform, it served us communication and technical support for the ponderable activities of the course and the Teams platform for virtual classes. Using Microsoft Teams we were able to establish contact with the students since by having video calls we can see them in a timely manner way when they are in the session, facilitating feedback on a concern or question. In addition, the Teams platform allowed us to create teams or rooms where, in isolation from the general group, they can work in teams of 6 people to perform the exercises collaboratively. In addition, by conducting evaluations with written exams in virtual form, time and costs could be reduced by facilitating the use of techniques to evaluate larger and more diversified groups, allowing the development of new forms of evaluation and their integration with other learning activities, as well as immediate feedback. based on its results, it offers greater opportunities to practice the knowledge and skills acquired. Finally, the main problem of evaluation in a virtual or remote environment is usually that of reliability, since "it can induce plagiarism" And this is eliminated by the supervision with the camera on while answering their written evaluations. The question arose if there would be a difference in the averages of the group that took the subject virtually against the averages of previous groups that took it in person. The grades obtained with the group from the August-December 2020 period (virtual classes) were compared to two groups from previous years 2019 and 2018 who attended the learning unit in person, observing a marked difference.
\end{abstract}

Keywords: Teaching, Virtual, Mathematics, Skills Development

\section{Introduction}

It is not news that the current situation had not been foreseen, however, human beings adapt to change, the pandemic practically forced us to modify many of our common tasks, and one of them was undoubtedly face-toface classes $[1,17]$ Our commitment as teachers is to develop in our students skills that allow them to respond to the demands of the labor and social market. So what virtual teaching techniques and strategies should be implemented for students to build meaningful learning? [3] Teachers had to modify our programs, assignments, and ways of teaching the class virtually $[7,10]$. Faced with the contingency, teachers face a new challenge: virtual or virtual face-to-face (mixed) teaching. As math teachers, our goal was to take advantage of the situation so that students could develop skills - such as reading, writing and speaking mathematically - which allowed me to identify areas of opportunity for work $[2,13]$. In this work we share the experience of a virtual mathematics course under the modality of competencies at the bachelor's level in the Clinical Chemical Biologist career that is taught at the Faculty of Medicine of the Autonomous University of Nuevo León. Through the use of the Moodle platform, it served us communication and technical support for the ponderable activities of the course and the Teams platform for virtual classes. Using Microsoft Teams we were able to establish contact with the students since by having video calls we can see them in a timely manner way when they are 
in the session, facilitating feedback on a concern or question. In addition, the Teams platform allowed us to create teams or rooms where, in isolation from the general group, they can work in teams of 6 people to perform the exercises collaboratively. In addition, by conducting evaluations with written exams in virtual form, time and costs could be reduced by facilitating the use of techniques to evaluate larger and more diversified groups, allowing the development of new forms of evaluation and their integration with other learning activities, as well as immediate feedback. based on its results, it offers greater opportunities to practice the knowledge and skills acquired. Finally, the main problem of evaluation in a virtual or remote environment is usually that of reliability, since "it can induce plagiarism" [4]. And this is eliminated by the supervision with the camera on while answering their written evaluations. The question arose if there would be a difference in the averages of the group that took the subject virtually against the averages of previous groups that took it in person. The grades obtained with the group from the August-December 2020 period (virtual classes) were compared to two groups from previous years 2019 and 2018 who attended the learning unit in person, observing a marked difference.

\section{Problem Statement}

The difficulty of teaching the higher mathematics chair to two groups of 40 students each virtually, is addressed through the execution of exercises in class and the explanation of these, as well as its procedure, making use of digital platforms so that the class is more attractive and with active participation of each one of the students.

\section{Methodology}

The Microsoft Teams platform will be used as a virtual classroom to carry out the theoretical sessions of the higher Mathematics course that is taught in the first semester of the QCB career with a duration of 60 minutes. In the Teams platform, the formation of subgroups was carried out, remembering that the theory groups are 40 students (in each TEAMS team, these subgroups or channels were established as "rooms" 6 in this case) where at the end of each session (15 min approx. before ending) they were invited to leave the general session and enter their work room, in this way, the teacher entered each room at the request of the students who had any questions.

Another strategy used was the Nearpood digital resource [12], where in this application the teacher was creating different presentations that include slides, interactive activities (time to climb) where the concepts or exercises seen in that session were reviewed, as well as the use of simulators for different topics such as: equation of the line, clearing of equations, quadratic equation among others. The simulator proposes different levels of complexity in the learning processes, so that each student identifies the state of her skills and knowledge, constructively looks for an optimal point that homogenizes it with the group. [6]

For the explanation of the problems and their resolution, the whiteboard application was used in the Teams session.

Assessments [9], such as weekly quizzes and midterms were applied using the Moodle platform [11] to solve them and Microsoft Teams simultaneously, the latter to keep their cameras on during their exam.

Next, the evaluation part of the Analytical Program based on higher Mathematics competencies is attached.

Table 1. Assessment guide for higher mathematics subject.

\begin{tabular}{|c|c|c|}
\hline Stage 1 & Evidence 1. Problem solving exam with arithmeticoperations and fundamental algebraic algorithms. & $10 \%$ \\
\hline Stage 1 & Evidence 2. Problem solving exam with algebraicalgorithms involving equations. & $10 \%$ \\
\hline Stage 1 & 1.1. Questionnaire on the context of the UA. & $2 \%$ \\
\hline Stage 1 & 1.2. Essay on the importance of the UA in theeducational program of QCB. & $2 \%$ \\
\hline Stage 1 & 1.3. Concept maps indicated by the teacher. & $2 \%$ \\
\hline Stage 1 & 1.4. Classroom resolution of problems where arithmetic operations and algebraic algorithms are used. & $4 \%$ \\
\hline Stage 1 & $\begin{array}{l}\text { 1.5. Extra-classroom resolution of general problems and / or the field of chemistry where arithmetic operations and algebraic } \\
\text { algorithms are used. }\end{array}$ & $6 \%$ \\
\hline Stage 2 & Evidence 3 . Problem solving exam with transcendent functions analytical geometry and trigonometry. & $10 \%$ \\
\hline Stage 2 & 2.1. Concept maps indicated by the teacher. & $2 \%$ \\
\hline Stage 2 & 2.2. Classroom resolution of problems using analytical geometry, trigonometry, and logarithmic and exponential functions. & $4 \%$ \\
\hline Stage 2 & $\begin{array}{l}\text { 2.3. Extra-classroom resolution of general problems and / or the field of chemistry where analytical geometry, trigonometry } \\
\text { and logarithmic and exponential functions are used. }\end{array}$ & $6 \%$ \\
\hline Stage 3 & Evidence 4. Problem solving exam with differential and integral precalculus. & $10 \%$ \\
\hline Stage 3 & 3.1. Concept maps indicated by the teacher. & $2 \%$ \\
\hline Stage 3 & 3.2. Resolution in the classroom of problems where limits, continuity, derivatives, integrals and differential equations are used. & $4 \%$ \\
\hline Stage 3 & $\begin{array}{l}\text { 3.3. Extra-classroom resolution of general problems and / or the field of chemistry where limits, continuity, derivatives, } \\
\text { integrals and differential equations are used. }\end{array}$ & $6 \%$ \\
\hline \multicolumn{2}{|c|}{ Integrative Learning Product } & $20 \%$ \\
\hline
\end{tabular}

\section{Results}

Comparing the grades of the virtual semester August December 2020 vs two previous semesters August -
December 2019 and August - December 2018, it was observed that the number of students failed in the first opportunity was only 5\% (4 of 80 ) for the virtual semester and for the course of 2019 was $31 \%$ (25 out of 80 ) and in 2018 it was $35 \%$ ( 28 out of 80 ). 
A survey was applied to the students of the virtual semester, and these were the results:

1. Do you consider that the time taken for each topic was sufficient?

$\begin{array}{ll}\text { si si fue suficiente } & 55 \\ \text { en forma parcial es suficiente } & 14 \\ \text { faltó mas tiempo } & 4 \\ \text { no fué suficiente } & 1\end{array}$

2. About the evidence exercises, were they clear?

$\begin{array}{ll}\text { si son muy claros } & 61 \\ \text { son claros } & 13 \\ \text { poco claros } & 0 \\ \text { nada claros } & 0\end{array}$

3. In the quizzes, are the items related to the topics reviewed?

$\begin{array}{ll}\text { si están relaciondos } & 71 \\ \text { están parcialmente relacionados } & 3 \\ \text { casi no están relacionados } & 0 \\ \text { no están relacionados } & 0\end{array}$

4. In the midterm exams, do you think the questions correspond to the topics reviewed?

$\begin{array}{ll}\text { si corresponden totalmente } & 69 \\ \text { parcialmente corresponden } & 5 \\ \text { muy poco corresponden } & 0 \\ \text { en nada corresponde } & 0\end{array}$

5. On topics related to the Nerst, Hasselbach, Calisus chemical equilibrium equation and liquid extraction. How was your understanding and / or rating?

$\begin{array}{lc}\text { muy útil } & 42 \\ \text { útil } & 21 \\ \text { poco útil } & 8 \\ \text { nada útil } & 3\end{array}$

6. How do you consider the usefulness of performing the team exercises in their respective rooms in Teams?

$\begin{array}{ll}\text { muy provechoso } & 40 \\ \text { provechoso } & 29 \\ \text { poco provechoso } & 4 \\ \text { nada provechoso } & 1\end{array}$

7. Making maps prior to the theoretical sessions, do you consider that it was:

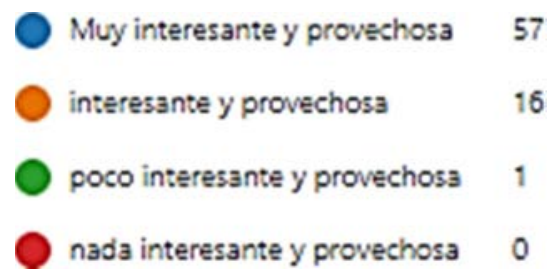

8. How do you consider the experience of interviewing the professors of the UA of your career about the usefulness of mathematics?

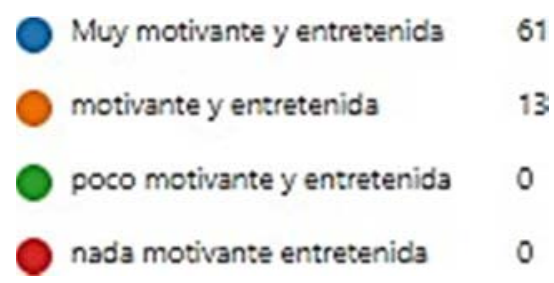

9. How do you evaluate the use of the Nearpod platform in the case of the simulators and the Time to Climb activity for the activities of the exercises in class?

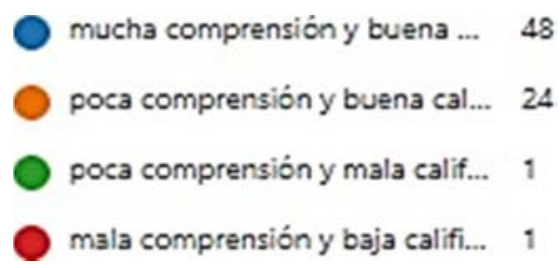

10. Comments on the math class.

\begin{tabular}{|c|c|}
\hline Id. & Respuestas \\
\hline \multicolumn{2}{|r|}{ Gracias por la dedicación y el tiempo } \\
\hline 14 & Fue la clase que mas disfrute durante el semestre, gracias por todo c: \\
\hline 20 & $\begin{array}{l}\text { Me ayudó mucho realizar mapas previos a las clases y las actividades } \\
\text { en nearpod }\end{array}$ \\
\hline 36 & Una de las materias que más disfruté \\
\hline 45 & $\begin{array}{l}\text { Aprendi cosas nuevas y reforcé conocimientos que ya tenía de los } \\
\text { temas, también le agradezco mucho a la maestra Judith y a la maestra } \\
\text { Samantha por sus enseñanzas }<3\end{array}$ \\
\hline 42 & $\begin{array}{l}\text { Disfruté mucho de las clases y de cómo fue transmitido el } \\
\text { conocimiento }\end{array}$ \\
\hline 7 & $\begin{array}{l}\text { La UA de matemáticas fue una materia muy buena y considero que } \\
\text { todo esto fue posible gracias a la Dra. Judith y a la Maestra Samantha. } \\
\text { Fue una experiencia muy buena debido a que siempre hubo un } \\
\text { compromiso por parte de ellas y por parte de los alumnos. }\end{array}$ \\
\hline 4 & La impartición del curso fue muy buena \\
\hline 46 & Muy buena materia y exelentes maestras, hacen que disfrutes la clase \\
\hline 43 & me gusta la manera en que se trabaja \\
\hline 41 & Todo bien todo perfecto uwu \\
\hline 34 & $\begin{array}{l}\text { En algunos que dice poco entendimiento o asi no es como tal poco, } \\
\text { sino mas o menos solo que no estaba esa opción. Graciaspor todo } \\
\text { maestra }\end{array}$ \\
\hline 12 & $\begin{array}{l}\text { Excelente unidad de aprendizaje, catedráticos muy bien preparados, } \\
\text { consejos para las demás actividades de aprendizaje y motivación para } \\
\text { seguir adelante. Gracias por todo su esfuerzo en está nueva modalidad, } \\
\text { por su preparación previa a clase y hacer que aprendamos a pesar de } \\
\text { las circunstancias }\end{array}$ \\
\hline
\end{tabular}


30 Mi clase favorita, las explicaciones eran claras así como los ejercicios

33 excelentes maestras:)

40 Me gusto mucho la dinámica de los mapas y el tiempo de los exámenes fue el adecuado para terminar bien el mismo.

6 a mi me pareció muy interesante y atractivo

35 Creo que el hecho de tener una maestra que nos explica correctamente y si no entendemos algo se regresa a explicar, ayuda mucho al desempeño en la unidad de aprendizaje.

28 La explicación de los temas fue muy buena, me hubiera gustado mas ejercicios para practicar más

2 Una exelente doctora, temas muy bien explicados y nos alenta a seguir a

8 Se me hizo muy fácil Gracias a la maestra Judith y Samantha

25 Una UA muy útil y con maestras muy atentas y dedicadas:)

16 Me gustó mucho su forma de enseñar

37 Muy interesante la materia.

21 Muy buenas profesoras

23 Muchas gracias por su tiempo, es de los mejores profesores que he conocido en estos años que llevo como estudiante.

Figure 1. Comments on the math class.

Here are some examples of the activities on the Nearpood platform.

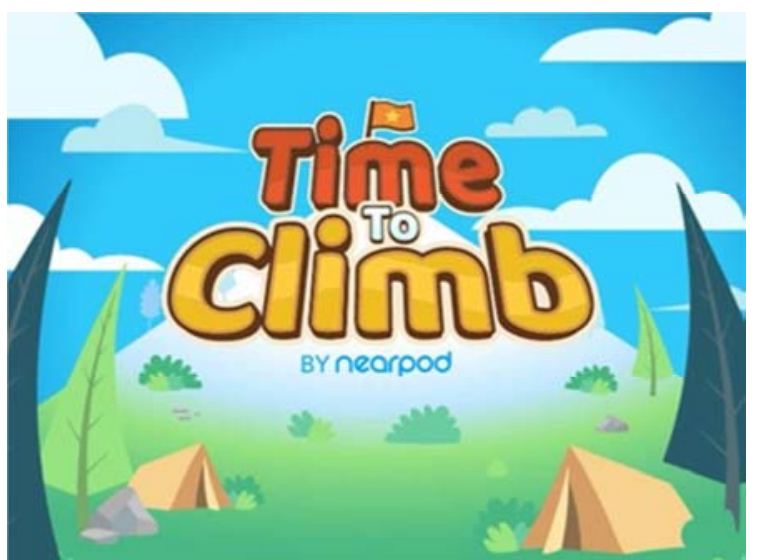

Figure 2. Examples of activities on the Nearpod platform.

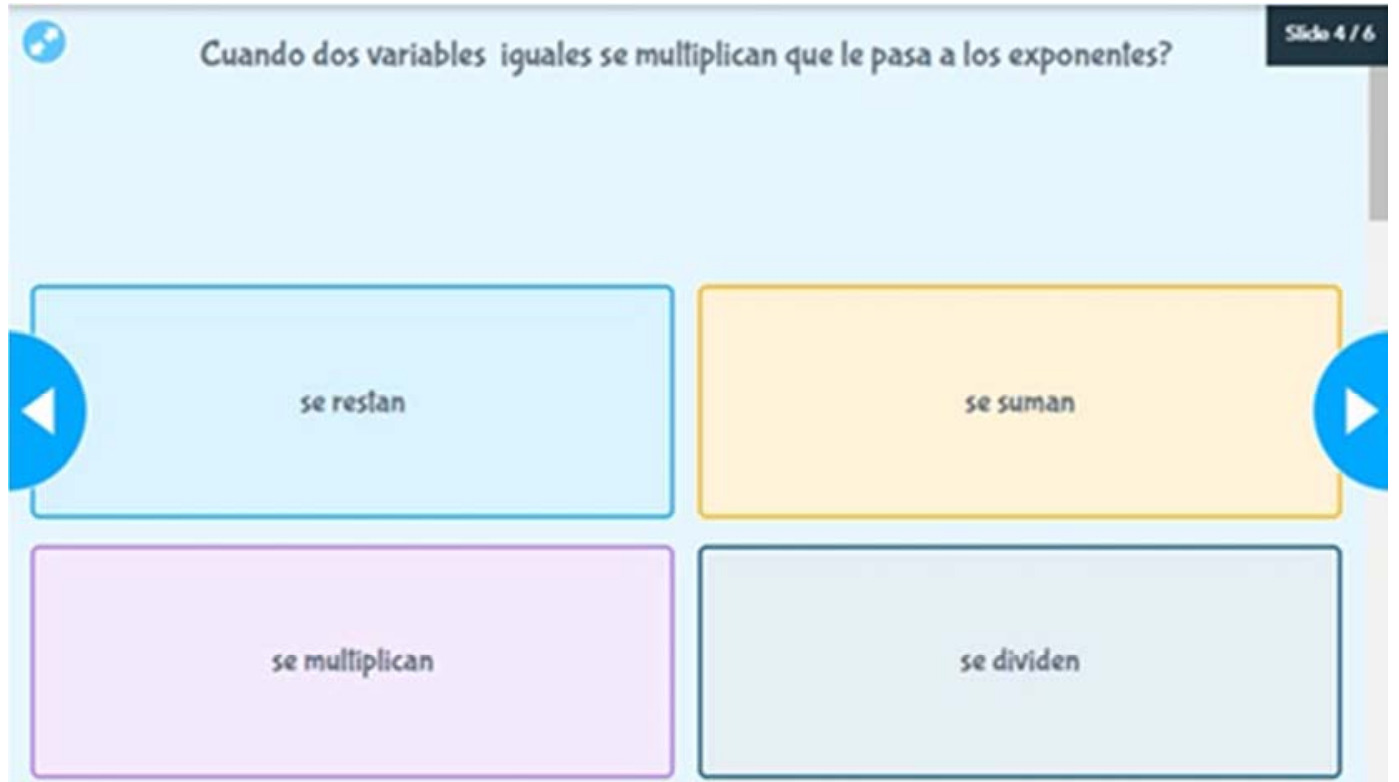

Figure 3. Time to Climb question format.

Finally, the grades obtained from the students of the 2020 generation vs the 2018 and 2019 generation are attached.

Table 2. Grades obtained from students of the 2020 generation vs the 2018 and 2019 generation.

\begin{tabular}{lll}
\hline $\mathbf{2 0 1 8}$ & $\mathbf{2 0 1 9}$ & $\mathbf{2 0 2 0}$ \\
\hline 78.0 & 78.7 & 70.0 \\
60.9 & 60.7 & 81.0 \\
70.3 & 89.7 & 87.0 \\
66.2 & 72.4 & 81.0 \\
68.5 & 78.8 & 86.0 \\
66.1 & 82.9 & 76.0 \\
82.6 & 79.9 & 78.0 \\
77.2 & 84.6 & 77.0 \\
75.5 & 69.5 & 71.0 \\
63.0 & 73.5 & 85.0 \\
79.8 & 61.9 & 86.0 \\
70.3 & 76.6 & 83.0 \\
71.4 & 73.6 & 82.0 \\
72.8 & 68.9 & 66.0 \\
73.6 & 87.9 & 67.0 \\
\hline
\end{tabular}

\begin{tabular}{lll}
\hline $\mathbf{2 0 1 8}$ & $\mathbf{2 0 1 9}$ & $\mathbf{2 0 2 0}$ \\
\hline 65.3 & 70.0 & 94.0 \\
86.0 & 55.9 & 90.0 \\
66.6 & 45.9 & 84.0 \\
78.9 & 78.3 & 83.0 \\
78.9 & 60.1 & 94.0 \\
79.4 & 79.3 & 81.0 \\
69.9 & 80.1 & 77.0 \\
71.4 & 75.1 & 83.0 \\
79.5 & 62.7 & 80.0 \\
75.0 & 55.2 & 83.0 \\
74.5 & 78.5 & 91.0 \\
86.0 & 71.4 & 85.0 \\
74.3 & 88.9 & 85.0 \\
71.7 & 74.3 & 83.0 \\
74.2 & 73.1 & 84.0 \\
78.8 & 83.3 & 86.0 \\
89.0 & 72.5 & 77.0 \\
79.4 & 87.7 & 78.0 \\
59.3 & 74.2 & 73 \\
75.8 & 84.3 & 90.0 \\
76.0 & 77.6 & 87.0 \\
\hline
\end{tabular}




\begin{tabular}{|c|c|c|}
\hline 2018 & 2019 & 2020 \\
\hline 76.8 & 24.8 & 81.0 \\
\hline 81.3 & 73.3 & 77.0 \\
\hline 76.6 & 11.0 & 91.0 \\
\hline 76.4 & 51.3 & 92.0 \\
\hline 82.3 & 76.1 & 80.0 \\
\hline 71.7 & 72.6 & 91.0 \\
\hline 83.9 & 62.8 & 86.0 \\
\hline 79.8 & 33.2 & 86.0 \\
\hline 83.6 & 75.7 & 88.0 \\
\hline 93.8 & 83.1 & 80.0 \\
\hline 81.0 & 77.0 & 69.0 \\
\hline 32.9 & 61.9 & 81.0 \\
\hline 73.6 & 72.5 & 91.0 \\
\hline 81.9 & 89.5 & 90.0 \\
\hline 73.1 & 66.9 & 86.0 \\
\hline 50.3 & 74.4 & 78.0 \\
\hline 74.8 & 69.3 & 74.0 \\
\hline 66.5 & 73.2 & 80.0 \\
\hline 66.8 & 86.1 & 63.0 \\
\hline 78.1 & 81.5 & 91.0 \\
\hline 75.1 & 85.7 & 84.0 \\
\hline 78.9 & 52.5 & 74.0 \\
\hline 87.7 & 75.7 & 83.0 \\
\hline 74.1 & 71.4 & 76.0 \\
\hline 73.3 & 79.4 & 86.0 \\
\hline 64.6 & 64.7 & 86.0 \\
\hline 68.0 & 75.9 & 97.0 \\
\hline 65.8 & 70.5 & 90.0 \\
\hline 78.8 & 65.1 & 86.0 \\
\hline 66.2 & 63.9 & 89.0 \\
\hline 70.9 & 87.4 & 82.0 \\
\hline 80.9 & 65.9 & 85.0 \\
\hline 64.5 & 77.3 & 86.0 \\
\hline 73.1 & 74.7 & 96.0 \\
\hline 67.7 & 69.1 & 92.0 \\
\hline 75.4 & 59.9 & 94.0 \\
\hline 74.8 & 83.8 & 12.0 \\
\hline 71.5 & 67.8 & 79.0 \\
\hline 77.1 & 85.7 & 90.0 \\
\hline 72.8 & 85.4 & 87.0 \\
\hline \multirow[t]{4}{*}{68.6} & 91.0 & 88 \\
\hline & 59.2 & 88 \\
\hline & 80.1 & 86 \\
\hline & 78.6 & 80 \\
\hline
\end{tabular}

\section{Discussion}

A comparison of the performance of the 2018 and 2019 generations was carried out, which was carried out in person, against the 2020 generation, which was virtual or online. When observing the results, a better performance of the students is demonstrated based on their grades and the percentage of passes, in this way, it is recommended to consider that they are quite possibly more suited to technology and that is the reason for their success.

Based on the survey, it is observed in the areas where issues related to their career are reviewed and the application of first degree equations and clearances that present a certain degree of difficulty to make this correlation, it is an area of opportunity to remedy.

Also, in the survey they state that the use of virtual rooms is good, but not excellent, surely because the time in which the teacher visits the rooms is very short, it will be necessary to consider giving more time to this activity or having more than two teachers during the session.

\section{Conclusion}

It was possible to compare the academic performance of Higher Mathematics students of the Clinical Chemist Biologist career when carrying out the class in person and virtually, showing better results and learning when it was carried out virtually using digital platforms. It is proposed in an important way to increase the use of educational digital platforms that accompany the best learning of the student.

It should not be forgotten that the teacher is an essential element to improve the quality of the educational processes in the distance and virtual methodology, insofar as they interact with their students in an empathic, proactive, motivating, and dialogical way in order to favor assimilation of the new knowledge. His intervention must stimulate and guide the student, through didactic learning situations and various strategies that help him overcome the difficulties encountered when approaching a problem situation $[5,15]$.

\section{References}

[1] Alejandre, J. L. (2013). Experiencia docente en un curso cero semipresencial. Departamento De Matemática Aplicada. Universidad de Zaragoza.

[2] Márquez, G. (2020). Enseñar matemáticas en tiempos de pandemia. Blog de Educació nnexos. https://educacion.nexos.com.mx/?p=2353

[3] E- Learning Masters (2017). Técnicas y estrategias de enseñanza virtual. http://elearningmasters.galileo.edu/2017/10/17/tecnicas-yestrategias-de-ensenanza-virtual/

[4] Cano, C. (2005). La evaluación del aprendizaje en ambientes virtuales. Congreso Nacional de Investigación Educativa. Entornos virtuales de aprendizaje. http://www.comie.org.mx/congreso/memoriaelectronica/v10/p df/area_tematica_07/ponencias/0275-F.pdf

[5] Mendoza, H. (2019). El rol del docente de matemáticas en educación a distancia y virtual universitaria. Un estudio en la Universidad pedagógica y Tecnológica de Colombia. Formación Universitaria.

[6] Torres, S. (2015). Laboratorio virtual de matemáticas como estrategia didáctica para fomentar el pensamiento lógico. Revista Academia y Virtualidad.

[7] Delgado, P. (2020). La enseñanza de las matemáticas requiere una urgente reestructuración, señala nuevo reporte. Observatorio Instituto para El Futuro de la Educación. ITESM.

[8] Juan, A. (2012). Aprendizaje virtual de las matemáticas. Revista de Universidad y Sociedad del conocimiento. Universities and Knowlegde Society Journal.

[9] Templeaar, D. (2012). El papel de los exámenes formativos digitales en el aprendizaje virtual de matemáticas: un estudio de Caso en los Países Bajos. Revista de Universidad y sociedad del conocimiento. Universities and Knowlegde Society Journal. 
[10] Albano, G. (2012). Conocimientos destrezas y competencias un modelo para aprender matemáticas en un entorno virtual. Revista de Universidad y sociedad del conocimiento. Universities and Knowlegde Society Journal.

[11] Blanco, M. (2012). Los cuestionarios del entorno Moodle: su contribución a la evaluación virtual formativa de los alumnos de matemáticas de primer año de las titulaciones de Ingeniería. Universities and Knowlegde Society Journal.

[12] Cuypers, H. (2012). Teaching Mathematics Online: Emergent Technologies and Methodologies, editado por Ángel A. Juan, María A. Huertas, Sven Trenholm y Cristina Steegmann» [reseña en línea]. Revista de Universidad y Sociedad del Conocimiento (RUSC). vol. 9, n. ${ }^{\circ} 1$, págs. 184-189.

[13] Collí, S. (2020). La enseñanza de las matemáticas: una reflexión sobre su transformación necesaria en tiempos de contingencia. Universidad Autónoma de Yucatán Mérida, Yucatán.

[14] Laguna, M. (2020). Hacer matemáticas en tiempos de pandemia. Reflexiones para volver a la escuela. Educación Futura.

[15] Ortíz, E. (2020). Impulsando la educación matemática a través de la tecnología durante y después de la pandemia. Blog BID, mejorando vidas. 